\title{
Solen, jorden, bäcken i diktsamlingen Solen min far
}

\section{Av Margareta Petersson}

\author{
144. å vera \\ og gløyme \\ at ein er
}

I Norden finns en växande grupp författare som ofta kallas postkoloniala. Det betyder vanligen att de använder motiv som associeras med koloniala situationer. Huvudpersonen i islänningen Kristjana Gunnars The Prowler (1989) identifierar sig exempelvis som vit inuit under skolgången i Danmark; i romanen Prästen (2004), som handlar om identitetskriser i Nordnorge, väver Hanne Ørstavik in sameupproret i Kautokeino; Kim Leine fiktionaliserar sina erfarenheter som sjuksköterska på Grönland i Kalak (2007), där rasismen på sjukhuset i Nuuk uttrycker koloniala attityder. Man säger gärna att författare från postkoloniala områden "skriver tillbaka” mot imperierna och ger nya perspektiv på det förflutna och samtiden. De "återkräver" sina länder och befriar sin kultur från en kolonial makts begränsande tolkningshorisont.

Jag tänker pröva rimligheten i påståendet utifrån diktsamlingen Solen min far av den samiske författaren Nils-Aslak Valkeapää (1943-2001). Det är naturligtvis inte den enda tänkbara kontexten för hans verk. Han kan också sättas in i de samhällskritiska 1960- och 70-talen, eftersom han på många sätt var en outsider och rebell som Cornelis Vreeswijk, vars viskonst insiktsfullt analyserats av Ulf Carlsson. ${ }^{1}$ Vad är då det specifika med den postkoloniala förståelsen?
416. de var fina
lärda herrar
kunde inte sitta vid elden

Satiriska bilder av lärda herrar, byråkrater och maktmänniskor var legio under den här perioden. Vreeswijk skrev gärna om dem. Det låga tonläget hos Valkeapää, i varje fall när man bara läser dikterna, är annorlunda än samtidens. I hans dikter framträder de lärda med lagböcker och lagar de själva stiftat, som ger dem rätten till samiskt land. Linné var en av de lärda som tidigt reste till samiskt område. Han förmådde bara uppfatta samiska livsformer som ineffektiva och onormala; hans råd var att samerna skulle göras bofasta, lära sig stängsla marker och bygga skjul till renarna. Så skulle de civiliseras och föras in i den moderna tiden. Det fanns en enda tänkbar väg in i denna: den Sverige gått

1 Ulf Carlsson, Cornelis Vreeswijk: artist-vispoet-lyriker, Malmö 1996. 
och som samerna - lite försenade - nu skulle följa. Man hittar liknande förhållningssätt till ursprungsfolk i andra delar av världen. ${ }^{2}$ Valkeapää aktualiserar en lång tradition av oförmåga att tänka utanför sin samtids dominerande tankebanor vilket lett till en bild av den samiska kulturen som fylld av brister.

Kritiken av den ofta dolda kopplingen mellan kunskap och makt är vanlig i postkoloniala sammanhang. Valkeapää lyfter fram en annan kunskapsform, där makten inte får något utrymme. Förmågan att sitta vid elden kan läsas som en konst att vara stilla mitt i samtidens rastlöshet. Elden återkommer i samlingen och konnoterar samtal, sammanhang och berättelser. Den antyder en speciell typ av förmåga som kan finnas i samiska livsformer. Genom att sätta dessa i centrum och rikta blicken mot främmande "lärda herrar” anlägger Valkeapää ett perspektiv, som påminner om det som kallats "provincializing Europe" och som innebär att de nordiska nationalstaterna och deras tankeformer hamnar i periferin. ${ }^{3}$

Solen min far kom ut i sin första utgåva på nordsamiska år 1989 - mitt i en period av samisk mobilisering mot storsamhällets koloniala förtryck. ${ }^{4}$ Den innehöll då närmare 400 historiska fotografier hämtade från olika arkiv och museer - på samer, renar, livsformer och renskötsel. ${ }^{5}$ Boken kom senare i en skandinavisk utgåva år 1991, som inte innehåller några foton och där språket växlar mellan nynorsk, bokmål och svenska. Det är denna utgåva jag använder här. De borttagna fotografierna var hämtade från resenärer och vetenskapsmän från slutet av 1800-talet och början av 1900-talet och utgjordes delvis av rasbiologiska forskningsbilder. Bilderboken riktade sig till samerna, har Valkeapää framhållit, och kan ha innehållit en politisk appell genom sammanställningen av exotiserande och rasistiska bilder. Utgåvan från 1991 hade en bredare publik i sikte. Parallellt med boken har Valkeapää komponerat musik till dikterna och gett ut en cdskiva, där han dels läser, suggestivt, ibland nästan viskande, dels sjunger eller jojkar dikterna.

Titeln på samlingen Solen min far anspelar på en samisk myt om att samerna är solens barn. ${ }^{6}$ Diktsamlingen inleds med vår, morgon och jordens födelse och namngivning. Den avslutas med höst, ålderdom och död. Det individuella livet skrivs in i ett kosmiskt men också ett politiskt sammanhang. Det är som hos många ursprungsbefolkningar jorden som är den födande modern. Valkeapää blev under sitt liv allt mer engagerad i ursprungsfolkens gemensamma problem. Överallt har främmande sätt att förstå förhållandet till jord och mark införts: som tanken att man kan äga marken man trampar och

\footnotetext{
2 Forskargruppen "Concurrences" vid Linnéuniversitetet undersöker koloniala och postkoloniala platser, röster och arkiv. Gunlög Fur och Maria Olaussen i gruppen arbetar med Linnés Iter Lapponicum. Lappländska resan och har inspirerat raderna om Linné.

3 Dipesh Chakrabarty myntade företeelsen i sin bok, Provincializing Europe. Postcolonial Thought and Historical Difference, Princeton 2000.

4 Anne Heith, "Särskiljandets logik i en kolonial och en antikolonial diskurs. Nils-Aslak Vakeapääs Beaivi áhčažan, Edda 2010:4, s. 41.

5 Fotografierna har noggrant beskrivits av Heith.

6 Kathleen Osgood Dana, Áillohaš. The Shaman-poet and his Govadas-Image Drum. A Literary Ecology of Nils-Aslak Valkeapää, Oulu 2003, s. 37.
} 
luften man andas. För samerna, vana att vara norrmän i Norge och svenskar i Sverige och föra renhjordarna till de för årstiden bästa betesmarkerna (nr. 326), blev redan nationella gränsdragningar en inledning till att deras livsmöjligheter inskränktes.? Samma effekt hade älvregleringarna som "släcker forsarnas liv" (nr. 511). Problem av denna art får allt större utrymme i slutet av diktsamlingen och belyser att samerna lever i en kolonial ursituation.

Jojktraditionen, som hörs i diktsamlingens bakgrund, var på väg att dö ut bland samerna när Valkeapää vitaliserade den genom att kombinera den med moderna instrument, visor, populärmusik och jazz. ${ }^{8}$ Men traditionen är gammal och finns inte bara hos samerna utan hos flera folk inom det arktiska området. ${ }^{9}$ Den lär vara en av de mest ålderdomliga och ursprungliga formerna av musik, som finns inom Europas gränser. ${ }^{10}$ De äldsta skriftliga beläggen är från 1600-talet. ${ }^{11}$ Att jojken fördömdes och förbjöds av lappmarksmissionärerna som mörkaste hedendom beror på dess koppling till den hedniska schamanismen och till de suggestiva lapptrummorna. ”Jojken var ett trollmedel med vars hjälp man kunde försätta sig i trance och uppnå förbindelse med övernaturliga makter." ${ }_{12}$ Jojkare straffades, ibland med avrättning, och följden blev att jojken nästan helt utplånades. Att Valkeapää använde den gamla förbjudna jojken kan ses som ett sätt att återkräva traditionen.

Jojken är i hög grad knuten till naturen. Man jojkar ett fjäll, en sjö eller en älv (verbet är transitivt), som hör samman med minnen, traditioner och berättelser. Så kan jojken bli på en gång mycket personlig och en traditionsbärare. Den har några speciella drag. Upprepningar med allitteration och assonans används för att betona nyckelpassager. ${ }^{13}$ De har också en stark suggestiv kraft. Musikaliskt bygger man på en kombination av improvisation och utmejslade enkla melodier, som utnyttjar få tonsteg, glidningar mellan toner, svävande intervall, och tonhöjdsstegring mellan stroferna. Rytmen vilar på fast fixerade rytmiska formler. ${ }^{14}$ En grundrytm är hjärtats slag som återkommer i trummans slag och markens puls.

Det vanliga sättet att jojka var att sjunga utan instrument. Men idag används gärna instrument av olika slag. Valkeapää får ofta fram rytmen genom att klippa in ripors skratt, renars trav eller bjällror och forsande eller droppande vatten. Mest konsekvent genomförde han en sådan rytmisering i Fågelsymfonin från 1993. Han har fått många efterföljare som gått vidare med moderna musikinstrument, som Mari Boine och Sofia Jannok.

7 Först 1751 drogs gränsen mellan Sverige och Norge längs hela fjällkedjan. Harald Gustafsson, Nordens historia. En europeisk region under 1200 år, Lund 2010 (andra uppl.), s. 104.

8 Harald Gaski, "Nils-Aslak Valkeapää: Indigenous Voice and Multimedia Artist”, Arctic Discourses, red. Anka Ryall, Johan Schimanski och Henning Howlid Wærp, Cambridge 2010 s. 302.

9 Matts Arnberg, "Musikalisk kommentar”, Jojk, red. Matts Arnberg, Israel Ruong och Håkan Unsgaard, Stockholm 1969, s. 58.

10 Arnberg, s. 42.

11 Dana, s. 19.

12 Arnberg, s. 56

13 Dana, s. 36.

14 Arnberg, s. 54ff. 
Den första versionen av Solen min far var skriven på nordsamiska och detta har uppfattats som en vilja att göra detta som är det största av de samiska språken till ett levande och litterärt språk. ${ }^{15}$ På 1970-talet kunde fortfarande mycket få samer skriva på sitt modersmål. Det var ju länge förbjudet i skolundervisningen. Man skulle kunna uppfatta valet av nordsamiska som ett postkolonialt grepp - framför allt känt genom Ngugi wa Thiong’os val av sitt modersmål kikuyu framför den koloniala engelskan som litterärt språk.

När Valkeapää fick Nordiska rådets pris år 1997 för Solen min far, betonades i prismotiveringen den uråldriga kopplingen mellan religion och litteratur och att samerna inte hade någon konst som var avskild och placerad i en särskild sfär. Konsten var en del av livet. ${ }^{16}$ Den roll Valkeapää tar upp, och återupprättar, är just schamanens, vars vertikala rörelse i rummet uttrycks visuellt:

32. jag ristar dessa bilder till tiden
på stenen, trumman
folkens
liv
stiger
sjunker
som solen,
vinden

Och vidare: "när jag trummat en stund/ dras jag till en annan värld/ för att se” (nr. 33). "Jag flyger iväg" (nr. 42). Schamanrollen hänger väl samman med det mytiska anslaget i diktsamlingen som helhet. Men det är också en roll som manas fram ur förbud och glömska.

Schamanrollen kan tyckas påminna om romantikens bild av författaren som skådare och siare men har motsatta konnotationer. Snarare än förbund med Gud har schamanen ansetts ha kontakt med djävulen. En viktig aspekt av rolltagandet är att Valkeapää tycks återta en central del av samisk kultur och att han vänder den negativa bilden av schamanen och ger den ny mening. ${ }^{17}$

Bokpärmarna från utgåvan 1991 visar detaljer från en schamantrumma i vitt mot svart botten. Dikterna kan sägas vara inskrivna i trumman, som Valkeapää hämtat från den svenske etnografen Ernst Mankers Die lappische Zaubertrommel, vars andra del om trumman som källa till andliga traditioner kom 1950. Trumman eller delar av den återkommer på textsidorna och utgör samlingens symboliska centrum.

Valet av en schamanroll skulle också kunna antyda motstånd mot sekulariseringen, som är en oproblematiserad följeslagare till moderniteten. Religion tycks vanligen betraktas som ett övervunnet stadium i det moderna samhället, som dröjer sig kvar i samhällen som ”försenats” i utvecklingstrappan. Synsättet signalerar att det råder en primitiv likhet

15 Dana, s. 36 och 58.

16 Arild Linneberg, ”Om Nils-Aslak Valkeapää och Beaivi, Áhčážan”, Vagant 1988:9, s. 8.

17 Dana, s. $181 \mathrm{ff}$. 
mellan alla ursprungsfolk och en föreställning om att alla gudar och andeväsen talar med samma röst. En sådan abstraherad föreställning om religioner är släkt med försök att reducera historien till några få överordnade konstanter i syfte att beskriva utvecklingen som en och densamma överallt. ${ }^{18}$

Samlingen har episka dimensioner. Valkeapää skriver till exempel om varför han valde att inte arbeta med traditionell rennäring, trots att renen som många betonat har en särställning i hans poesi. Solen min far innehåller rentav en dikt som inte översatts, helt enkelt för att det inte finns ord på svenska eller norska för att översätta så många termer som har att göra med renen, renflocken och vandringen med renar under flytten mellan betesmarker. När Valkeapää så radikalt betonar att man inte kan översätta allt mellan olika kulturer, är det möjligt att han vill framhäva samiska skillnader och skapa ett motstånd mot förhärskande förenklingar. - Också typografiskt gestaltar han renar. Han har på olika ställen målat översiktsbilder av vandrande renflockar och här återskapar han formen genom att placera orden på sidan så att de visualiserar en långsamt vandrande utspridd renhjord. ${ }^{19}$

Valkeapää skulle ha kunnat ägna sitt liv åt arbete med renar. Men han gestaltar i samlingen ett sådant val som omöjligt eftersom han inte skulle ha kunnat bedriva en rationell renskötsel, som innebar att renar ibland måste avlivas. Han beskriver hur insikten drabbar honom när han ser in i en rens ögon: "i mina ögon dimma / i mitt sinne natt” (nr. 52). Det var en svaghet, skriver han. Ryktet om ”stackaren” spreds. Och effekten:

54. vem skulle trott svagheten som en utväg skröpligheten som ett hav andra världar uppenbarade sig nya

På klassiskt postkolonialt sätt lyckades han vända svagheten till styrka - till poesi, konst och musik. Att lyssna till bäckar och fåglar, till renars rop och ripors skratt, vinden, vidderna, ”vindviddene” (nr. 15) blev en livsform och en källa till skapande.

Naturdiktning har sagts vara ett av de utmärkande dragen för nordisk litteratur. Trots det har samisk litteratur nästan aldrig räknats till den nordiska litteraturen eller betraktats som viktig nog att ta upp i våra litteraturhistorier. Här finns åter en parallell till viskonstens Vreeswijk. Ändå har naturen en unik roll i denna litteratur. Till skillnad från annan lyrik med naturen som tema är Valkeapääs lyriska landskap just ett vidsträckt landskap, som inte är kopplat till ägande, till hus och trädgård, eller begränsat till en särskild naturtyp. Det samiska landskapet sträcker sig från hav och slätt till skog och fjäll. Det är inte idylliskt eller romantiskt, inte avskilt från betraktaren utan själva platsen för

18 Chakrabarty, s. 43ff.

19 Gaski har belyst detta fenomen (s. 312 f.) som Lars Elleström kallar”visuell ikonicitet” i Visuell ikonicitet i lyrik. En intermedial och semiotisk undersökning med speciellt fokus på svenskspråkig lyrik från sent 1900-tal, Hedemora 2011. 
hans liv, historia och minnen. Jojkning är en minneskonst fylld med intensiv känsla. Diktaren talar med bäckar, våren är en syster, jorden en moder. Han gestaltar en stark upplevelse av levande natur, en känsla av sammanhang: ”jeg taler med jorda / og hører bekkene svare/med lyd av sølv i rösten” (nr. 7). Historien om livet på jorden handlar inte bara om människan.

Diktens avslutning rymmer höst och ålderdom. Den har uppfattats som en döds- och undergångsmyt, kraftigt förstärkt av den politiska utvecklingen. Samtidens kortsiktiga vinstintressen, som drar in människor på hela klotet i samma rastlösa konsumtion, får här en skarp motbild. Samiska livsformer tycks innehålla alternativ till det stressade marknadsliberala trycket på naturens resurser. Så gör Valkeapää den samiska jojken giltig och angelägen långt utanför Sápmis gränser.

På många sätt är det meningsfullt att sätta in Valkeapää i ett postkolonialt sammanhang, som blixtbelyser vårt koloniala förflutna och våra kvardröjande koloniala attityder. Ett sådant sammanhang gör hans små historiska notiser begripliga och aktualiserar frågor kring kunskap och makt, språk och motstånd. Men om vi fixerar hans poesi till en enda tillbakavisande gest, ett postkolonialt svar på storsamhällets påståenden, riskerar vi att förlora hans egen individuella röst och vilja, vilket förminskar honom till en mycket lokal och därför exotisk och perifer författare. Det kan få oss att tro att han bara angår samer eller andra ursprungsfolk, när han i själva verket visar oss alla den katastrofala ekologiska obalansen på jordklotet. Med små medel gestaltar han kunskap och livsformer i förbund med naturen och en religiös tradition utanför den västerländska tankestilen - också den postkoloniala.

De tre raderna i inledningscitatet till den här artikeln sträcker sig långt utöver varje form av tillbakaskrivande och återkrävande. De visar en motbild, en möjlighet, kanske ett erbjudande.

\author{
142. i sommarnatta \\ talar eg til \\ fjøresteinane \\ og dei svarar \\ men eg skjønar ikkje deira språk
}

143. ventar

og kva ventar eg på

år etter år

144. å vera

och gløyme

at ein er

145. korleis fortelja

om stilla 
146. eg set meg ned

med føtene i kross

blir att for å sjå

eg skuvar ord bort

tankar

minne

kjensler

at natur

lydar

lukter

rett igjennom 